\title{
Culture, Politics \\ and Identity: \\ Critical Readings \\ on Gender in \\ Southeast Asia
}

\section{Clara Sarmento}

\section{Keywords}

Gender, women, Southeast Asia, identity, representation, globalisation epistemology

\begin{abstract}
This article discusses some critical readings of theoretical texts on gender in Southeast Asian countries, where the intersections of past and present, of the global and the local, capitalism, post-colonialism and post-modernism define the guidelines to explore the negotiation and evolution of gender concepts. Gender issues are located not only within structures of symbolic meaning, but also in relation to the historical and political forces that have marked a plurality of post-colonial contexts, where local notions about gender (in)equality and complementarity are constantly evolving.

This article claims that the previously silenced narratives of nonWestern women must be given a new role and status, in a modern transnational, interdisciplinary cultural grid. Narratives of everyday common life create spaces of empathy, and consequently, projects of action and research will be conducted in order to obtain concrete and useful results. However, many narratives of the everyday practice are actually stories of violence, a type of discourse generated by extreme poverty, substantial inequality and daily contact with terror. In addition, this article also analyses the role played by female characters in the building of the nation's narrative, both in colonial and post-colonial times, with its enduring stereotypes, dichotomies and metaphors of power.
\end{abstract}

Clara Sarmento is at the Centre for Intercultural Studies, ISCAP-IPP-Office 333, Rua Jaime Lopes Amorim, 4465-004 Mamede Infesta, Portugal. E-mail:clara. sarmento@iol.pt 


\section{Introduction: Gender, Intersections and Contingency}

In this article I discuss some critical readings of theoretical texts on gender in Southeast Asian countries, trying to establish their main concerns. At present, traditional forms of gender hegemony have been replaced by other, more powerful, yet more concealed forms. I intend to discuss some values related to traditional female roles, as well as the strategies used to recognise women in political and social fields, that are traditionally characterised by male dominance. The empowerment of womenboth at the individual level and on a broader scale, in society and the nation - is expressed in different ways at different periods of history as a consequence of cultural, economic, political, religious, social and also individual circumstances. In this article I argue that localisation and globalisation - with its associated discursive productions - do not form a dichotomy: localisation is a significant dimension of globalisation, in which local knowledge provides a dynamic counterpoint to global knowledge. The search for local concepts generates new ones that encourage the challenge of epistemological and phenomenological adaptation when doing gender studies in Southeast Asia, within a genuinely interdisciplinary and intercultural perspective.

Following this perspective, one question arises: how can anthropologists, sociologists and researchers in gender issues bring new perspectives to the study of gendered identities in Southeast Asia? The construction of gender is a fluid and contingent process, characterised by challenges, changes and ambivalence, so that any approach must be located within the network of ideological and material contexts of a given region, often a dynamic and evolving territory. In a post-colonial world-and specifically in the post-colonial space of Southeast Asia - the intersections of past and present, of the global and the local, define the parameters to explore the negotiation and evolution of gender concepts. On the one hand, studies on the experience, understanding, representation and daily 
renewal of gender issues examine the relationship of these factors with different levels of the social hierarchy in a specific region. On the other hand, these also reveal how different forms of consciousness and power locate bodies and sexualities as indicators of political, economic and cultural transformations. The study of emergent gender issues in contemporary Southeast Asia has, therefore, to consider the existing connections between processes of gender construction, ways of negotiating everyday life, diverse forms of power and the material forces that influence individuals, communities, nations and transnational arenas.

Ethnographies of the everyday gender experience, interrelated with different forms of domination and subordination, have suggested that gender dynamics are more properly contextualised within the fields of knowledge and power (ever-changing and expanding fields) of the different 'modernities' and their specificities. Indeed, in contemporary Southeast Asia, globalisation - in its various aspects - has been localised and reinvented in a multitude of modernities, marked by a perception of the local and the global strongly anchored in unique contexts. Therefore, gender issues are located not only within a structure of symbolic meanings, but also in relation to the historical and political forces that have marked a plurality of post-colonial territories. Local notions about male and female, inequality, equality and gender complementarity, along with myriad criteria of social prestige and stigma, are constantly evolving in countless dynamic post-colonial contexts. Representations and experiences related to gender are also filtered in various ways, not only through symbolic systems and patterns of class, but also through their relationship with a multiplicity of cultural conflicts, where issues as complex as the authority and authenticity of meanings and values are closely related to the material conditions that determine the distribution of wealth and power.

Since the 1960s, there has been intense economic growth in countries like Singapore, Malaysia, Thailand and Indonesia, when compared, for example, with the Philippines. This reality emphasises the contrast between different colonial formations in Southeast Asia, particularly in the way religion, ethnicity, development and nationality-related ideologies have influenced the experience and notions of gender in the postcolonial territory. Post-colonialism here relates to the actual situation of former Western colonies, now located somewhere between the colonial legacy, the attempt to reach a national consciousness and the policies of 
cultural conflict, in which different groups are simultaneously trying to set their own identities; these always under the strong influence of global hegemonies. Post-colonial societies, according to Achille Mbembe, are composed of a plurality of spheres and arenas, each with its own logic, and yet likely to be interwoven with other logics, in a continuous improvisation and negotiation (Mbembe, 1992, p. 5). This constant need to negotiate and construct identity underlies life in post-colonial Southeast Asian countries, self-defined as developing, multi-racial and multicultural. Under these conditions of mutability, cultural conflicts occur within ideological contexts associated with religious orthodoxies, invasive forms of capitalism and post-colonial nationalism, expressed by communities in a polyphony of narratives (Chatterjee, 1993). This network of post-colonial ideologies influences the conditions, characteristics and possibilities of daily negotiations and redefinitions of gender-related issues.

In certain historical and geographical circumstances, the negotiation of obligations, rights and meanings related to gender may develop into open defiance, if not at the national level, at least in local, ritual and personal aspects of everyday life. Gender-related challenges are thus located (and should be considered) in specific contexts, whose evolution is reflected in the interpretations by male and female, hegemonic and counterhegemonic, official and local, religious and secular sources of capital and labour. Consequently, one concludes that gender hegemony never exists by itself, but exercises its power at the intersection with other hierarchical domains, like individual identity, family, civil society, religion, nation and the international arena, with their specific gender constructions.

Gender relations in Southeast Asia cannot be considered as fixed systems, because they are grounded in conflicting ideologies in flux, which in turn create new possibilities for subversion and resistance. Such processes and dilemmas are visible in experiences as diverse as those of migrant workers from the Philippines and Thailand, of Javanese trader women from communities caught in the conflict between Islam and secularism and of the emerging middle class in Singapore. Spaces of gender conflict can be located both in village markets and urban centres, government offices and rural councils, universities and the mass media, suburban middle-class homes and circles of intellectuals, labour-exporting villages and capitalist work circuits. In all these spaces, conflicts of gender reflect - and also affect - the global networks of national and international interests. 
Similarly, in Southeast Asia the symbolic structure of gender relations is commonly based on binary oppositions of prestige versus stigma, strength versus weakness, and discipline versus irreverence. These pairs of opposites create the kind of social interdependencies that feed ambivalences among - and within — gender identities. In many symbolic constructions, the 'positive' depends on the 'negative', the 'strong' on the 'weak', which produces a dynamic and conflicting fusion of power, fear and desire, that strongly influences the construction of subjectivities (Ong and Peletz, 1995). One must bear in mind that the notion of gender (both male and female) is highly contingent and fluid, because it exists inside contexts created by different but interwoven webs of power. By analysing the complex changes in local notions of gender in the developing economies, policies and societies of Southeast Asia, this article tries to build effective epistemological bridges between anthropology, feminist and gender studies, cultural studies, ethnography, historiography and literary and translation studies.

\section{The Narrative of Everyday Practice}

What does an account of everyday life have to contribute to the current discourse of gender studies in Southeast Asia? Is everyday life similarly or differently manifested at the peripheries and semi-peripheries of the capitalist world system? How are the possibilities for emancipation inscribed in everyday practices, relationships and events of specific individuals and groups, which often take the form of new potential for autonomy, dissent or accommodation? What implications do recent transformations and old continuities in the nature of everyday life hold for the analyses of subjectivity, gender, ethnicity, identity and sexuality?

André Lefevere developed a theory of cultural grids, based on the works of Pierre Bourdieu and his concept of cultural capital. In Lefevere's schema, a kind of grid system can be mapped out that shows the role and place of texts and discourses within a culture and the role they might play in another culture. Such a system would clearly show that texts undergo all kinds of variations in status both inter-temporally and interculturally, and would help us to explain some of the contingencies of those changes (Bassnett and Lefevere, 1998). In the same manner, while discussing gender in translation, Sherry Simon points out that those 
spaces that were once identified as universal (such as the great humanist tradition, the canon of great books, the public space associated with democratic communication or the model of culture which sustained the ideal of citizenship) have now been exposed as being essentially expressive of the values of the white, European, middle-class male (Simon, 1996).

This is why life stories, case studies and interviews with women of every age, education and background must be considered as seriously valuable for an 'inside' study of gender in Southeast Asia, capable of generating encompassing theories. The previously silenced voices of these women (non-white, non-European, non-middle-class and nonmale) and the narratives they produce, have to be given a new role and status, in a modern transnational, interdisciplinary cultural grid: small voices instead of great books, the space of home instead of the public space - in other words, the narratives of everyday common life, read and deciphered in their own context. Moreover, by listening to women's voices and their life stories, we learn about their experiences, real needs, doubts, fears and requests. Because narratives of actual lives produced by human beings with a voice, a face and a name create spaces of empathy, consequently projects of action and research can be conducted in order to obtain useful results.

\section{Some Readings}

The first reading I would like to share is Telling Lives, Telling History: Autobiography and Historical imagination in Modern Indonesia, that compiles and analyses two autobiographical childhood memoirs translated into English for the first time. These unpretentious memoirs offer a clear and unique insight into life in Sumatra, in the early decades of the 20th century (Rodgers, 1995). Originally published shortly after the Indonesian revolution, the two authors remember their childhood in rural villages, Toba Batak and Minangkabau, at a time when the expansion of the printing press was starting to transform the local cultures of Sumatra. The narrative of childhood memories allowed the authors to reflect in a new light upon their identity, society, language and religion during an intricate historical moment, between colonial oppression, revolution and independence. Regardless of their personal nature, of their authors' 
gender (both male) and temporal distance, these narratives contain cultural and textual grids capable of generating theory, as Susan Rodgers argues in her introduction significantly entitled 'Imagining Modern Indonesia via Autobiography'. Indeed, autobiographical narratives establish a bridge between the individual and society and have a deep public resonance in contemporary Indonesia, where the process of individual growth and maturity is often remembered in a broader sense in terms similar to those that are used to reflect on society and the historical past. In Indonesia, both in urban centres and in rural communities, telling a life story invariably involves a narrative of passage through historical times and of transitions between different levels of personal and social awareness. Indonesian storytellers, like P. Pospos and Muhamad Radjab, the authors collected in Rodgers's book, tend to use similar symbols to represent historical and political periods as times of light and darkness, of maturation and evolution towards a higher intellectual conscience, when compared to earlier periods of social disparity and ignorance. In other words, Indonesian historical and individual memories are both animated by distinctive key scenarios and social images, closely linked together, sometimes confusing personal narratives with history. They also use common rhetorical and stylistic features of great aesthetic value and emerge as texts with deep social and cultural meaning. That is to say, verbal art grants life to the narrative of history, both in public and in private, through unusual and constantly evolving patterns, within a cultural framework that nurtures a sense of individual and national time.

In a different geographical field, but also dominated by lifestory telling voices, Women at the Crossroads: A Sri Lankan Perspective, edited by Sirima Kiribamune and Vidyamali Samarasinghe relies on interviews and case studies to deal with a wide spectrum of issues related to employment and women's social and domestic roles, in an Asian society faced with the dilemmas of economic and social change (Kiribamune and Samarasinghe, 1990). The authors include interdisciplinary studies on tradition and modernity; parliamentary politics; education; family law and social justice; the case of the Sri Lankan, Bengali and other Indian domestic maids/workers in the Persian Gulf states (Kuwait, United Arab Emirates, Saudi Arabia and Bahrain); school teachers; marriage, motherhood and employment. Modern Sri Lanka is also the field covered by Jayaweera (2002), in a collection of essays which reviews the different paths Sri Lankan women have taken to achieve 
greater political and economic empowerment and control over their lives during the 50-odd years that have elapsed since Sri Lanka gained political independence in 1948. The book opens with an overview of the various spheres where women are affected: law and human rights; the impact of continuing ethnic conflict and violence; education and employment; health and population; changes in social and intra-family structures; the emergence of women's organisations; reasons for upward mobility and endemic poverty. But all these topics take into serious consideration the voices of Sri Lankan women themselves, by studying and quoting extensively from interviews with women from different socioeconomic strata and with those who have experienced first-hand the effects of political upheaval and violence. Adopting a gender perspective, this volume discusses the impact on women of the social, political and economic developments that have occurred during these eventful decades. On the face of it, the country's record on gender issues has been remarkable: women have occupied and continue to occupy positions in the highest echelons of political power. The country ranks high on the list of developing nations in terms of its social indicators; and both men and women have enjoyed franchise since long before 1948 . However, a closer examination reveals that, despite all this, gender issues continue to be largely ignored in policy making and in important sectors of national development.

In South and Southeast Asian countries, a large number of women have been employed as teachers in primary to higher secondary schools and, though comparatively fewer in number, at college and university levels. This has given rise, however, to role conflicts in a womanteacher's everyday life experience. Based on extensive fieldwork and personal interviews in Sri Lanka, Nepal and India, Usha Nayar's Women Teachers in South Asia reveals patterns of continuity, discontinuity and change in the occupational mobility, role commitment and also role conflicts of women teachers in these three societies, as teaching at any level gradually becomes a specialised job, requiring a particular kind of training, skill and aptitude (Nayar, 1988). Tracing the growth and evolution of education and teaching as a profession for women in traditional Asian societies, this pioneering cross-cultural study shows that while at lower levels women teachers take their occupation almost as an extension of their family roles (in terms of space and time), at higher levels their family roles come into conflict with their profession, though they have in 
general displayed a remarkable capacity for evolving a certain compatibility between them.

When it comes to remunerated work outside the domestic space, gender roles and conflicts of identity become even more evident in professions that require a high level of academic education and offer both personal and economic power. For such women, new alternatives continuously interplay with the forces of adat (tradition) and religion, which are not always compatible, bearing in mind that what may be 'appropriate' according to tradition at home, may not be 'appropriate' according to modern corporate culture at work. In other words, gender identity in one realm does not necessarily travel well into another social situation.

In Java, Diane Lauren Wolf studied the dynamics of gender in domestic life during the period of strong industrialisation in rural Indonesia in the last decades of the 20th century. She focuses on the dynamics of intra-household decision-making processes and challenges certain preestablished notions about the strategies of economic organisation of low income families (Wolf, 1992). The lives and voices of young female factory workers (suggestively referred to as 'factory daughters'), here recorded and analysed in the first person, reveal the contradictions and complexities inherent to the process of industrial proletarisation and its mechanisms of change, as well as the meaning of such changes to the social actors involved.

The examination of the interactions that occur among young Javanese female workers, their families and the new factories of the capitalist system, places Wolf's study at the centre of several lines of enquiry: the effects of $(a)$ industrialisation on families, (b) the new international distribution of work on the lives of female factory workers and (c) the new model of economic organisation on rural communities in Southeast Asia. However, most studies about the relationship between third world women and the capitalist system tend to ignore the voices of women themselves, as in the case of Diane Elson and Ruth Pearson's article, 'An analysis of women's employment in third world export manufacturing' (1981), which does not contain a single quotation from an actual factory worker. Chandra Mohanty (1988), Aihwa Ong (1988), Lourdes Benería and Martha Roldan (1987) also state that women are commonly represented as undifferentiated, homogeneous, without a face or a name, by 'omniscient' authors who seem to grant more character and agency to capital, than to these women exploited by it. Lauren Wolf, who focused 
on the analytical register of the narrative of everyday practices, argues that women in these studies are represented as members of a passive labour reserve, whose behaviours are determined by distant economic agents. They are never represented as social agents capable of reflecting, reacting and critically interpreting their own living conditions. On the other hand, these studies often tend to argue that factory labour is a cause of degradation of status and marginalisation for women, in an implicit comparison with a non-capitalist or pre-capitalist past, in which women were autonomous, authentic and unexploited. However, this comparison derives, according to the author, from a certain romantic vision of rural life in Southeast Asia. Without denying that wages in factories are insufficient, working conditions adverse and that female workers are effectively subordinate subjects, one must bear in mind that in traditional rural societies too, exploitation and subordination are present, built into long hours of unpaid work under the supervision of parents or older male relatives. Furthermore, as many female factory workers are migrants living away from their households, most studies have usually ignored their family, domestic and social backgrounds. However, these have been incorporated into Wolf's research; therefore a more comprehensive and distinctive view of the relationship between woman, family and factory is seen.

Factory Daughters pays special attention to the control exercised by these young female workers over their own economic activities, personal income and marital options, including divorce (resulting from emotional and sexual dissatisfaction on the woman's part). This methodological option relates this research to more wide-ranging studies on economic strategies in rural Southeast Asia, since all decision-making processes studied here have a direct effect over the ways in which labour and capital are mobilised and used within the family sphere. Although it is true that these Javanese women play an important role in certain decisionmaking processes, it must be accepted that such 'options' are invariably confined by the narrow boundaries of poverty. Returning to the aforementioned intersections and contingencies inherent to gender issues, this study pays special attention to the confluence of state, industrial and domestic interests, of ideologies and of various types of family organisation, and how it affects the work of young rural women and their position in the labour market. For this reason, Lauren Wolf is careful to include a comparative analysis of the experiences narrated by Javanese factory 
workers with those of their Taiwanese counterparts. It is then possible to understand how, in two different Asian locations, the interests of parents, family, state and industrial capital converge at asymmetric points, with different and even contradictory effects on the women workers.

In conclusion, Factory Daughters proves that the domestic life of rural Javanese households, although centered on issues of work and survival, is much more complex than what has been portrayed by studies on the economic nature of work and income earning practices. Although members of these families do work extraordinarily hard to survive, interfamily relationships are not based solely on economic factors. For this reason, gender studies should attempt to expand towards an interactive and relational perspective, beyond mere material issues, following a demystifying reassessment of actual concepts about how families act, coerce, subordinate and manage their members. It would also be interesting to reassess the concept of 'third world woman', as a social agent simultaneously capable of conformity, passivity and resistance, in her daily performance of essential productive and reproductive activities. A new methodological perspective should use more appropriate terms to conceptualise the intra- and extra-family dynamics built around these women, and include approaches that will sustain in-depth researchesthe 'thick descriptions' of Clifford Geertz (1973) — on those interactions and their associate meanings, practices and local concepts.

\section{Narratives of Violence: The Everyday Practice of Terror}

Among the narratives of everyday practice, a particular and sadly universal reality stands out: the narrative of violence, a type of discourse generated by extreme poverty, strong relations of inequality, close contact with terror and sheer survival on a daily basis. Old and new realities created by violence require an adequate vocabulary, composed of words and metaphors with multiple meanings; new words whose meanings are created and shared by the affected community, because violence is described and somehow justified by most victims and some perpetrators. Violence against women may take multiple forms, wear several masks and play its hegemonic role in many scenarios. 
The case of Asian domestic aides in the Persian Gulf states, and their subhuman living conditions, already introduced in Women at the Crossroads, is the core of Michele Ruth Gamburd's The Kitchen Spoon's Handle, which focuses specifically on Sri Lankan migrant domestic workers (Gamburd, 2000). Domestic service abroad functions as a possible but uncertain response to social and economic changes, in a context of severe inequality inside the family, the community and the nation. This inequality is also evident in the macro relations between nations, races, religions and cultures, established by cross-border migratory flows. The case studies described in this book blend the painful stories and memories of returned migrants and their families and communities with interviews with government officials, recruiting agents and moneylenders, thus showing the sometimes sinister confluence of global and local processes in the lives of these women. I would like to emphasise that, in most of the cases presented here, violence against women is perpetrated by both male and female employers, as Asian domestic aides are seen as mere commodities without identity or rights, an expendable slave-like workforce that even a lower-middle-class family is able to afford.

But there are other forms of tacit violence and sanctioned exploitation of Asian women, as in the strange case of 'mail-order brides', who are advertised, selected and purchased through glossy paper catalogues and websites. Rolando Tolentino explores this practice in America and Canada (Tolentino, 1999). The 'mail-order bride' exists within a narrative of hegemony, of disguised violence, of a nostalgic discursive production that enhances the values of traditional family and ideal social order. But the mail-order bride herself, confined to a commodity trade, is deprived of an independent discourse. The functional third world woman's body is made symptomatic of the ideal first-world male nuclear family narrative. The catalogue's text brings into perspective the desire to situate women in an American/Canadian idyllic space, and at a time when women were idealised schoolgirls and perfect housewives. Firstworld men aim to regain the pleasure of authority through a conquest of those third world women who prove themselves worthy of redemption from their own kind. Nostalgia and gender and racial stereotypes are hence disguised under the language of philanthropy. The mail-order bride business depends on the catalogue's verbal and visual discourse about passive, devoted, submissive women, revealed as the very antithesis of the supposedly liberated first-world woman. 
War, however, is the domain of terror par-excellence. Women and children helplessly experience all sorts of violence, which has to be somehow represented through words and silences, through patterns of thought and behaviour, provided that they survive. Sasanka Perera's recollections, recorded in Stories of Survivors: Socio-Political Contexts of Female Headed Households in Post-Terror Southern Sri Lanka, for instance, describes the emergence and the institutionalisation of political violence in Southern Sri Lanka in the late 1980s (Perera, 1999). In this historical moment, female-headed households in Sri Lanka emerged as a social phenomenon in substantial numbers, after the two youth uprisings, one in the south among the Sinhalese and the other in the north among the Tamils. Men went to war and died violently, leaving women and children to face their lives amidst uncertainty, insecurity and terror. While undertaking a sociological inquiry into the lives of women and children, an inevitable political focus enters the research, as the complicity of the state in creating coercive patterns of governance becomes more and more visible.

Drawing upon extensive narratives of violence articulated by women, Perera's book captures both the structural and emotional upheaval that affect women and children during times of war, such as living daily with a tortured victim, the disruption of family, concerns over sexual harassment and re-marriage, consequences of trauma and the problem of missing relatives, the so-called 'disappeared'. This widespread culture of violence, with large scale destruction of life and property as well as thousands of arbitrary disappearances, coined new words and altered meanings for old words, such as the ones (old and new) used for designing 'terror', 'torture chamber', 'kidnapped' or 'the disappeared'. These words made a dramatic entrance into journalistic and popular discourse and eventually into the narrative of everyday experience.

Articulating violence, both as an agent and as an object, is a painful, difficult task, as it becomes evident in Alex Argenti-Pillen's Masking Terror: How Women Contain Violence in Southern Sri Lanka (ArgentiPillen, 2003). This book gives an account of the ways women from a community in the rural slums of Southern Sri Lanka talk about violence and its effects. The background of the soldiers - commonly depicted as perpetrators, because of the genocidal war crimes against Tamil communities - is reconstructed through the stories of their mothers, sisters, wives and grandmothers. In order to understand these stories, it is 
important to analyse the language in which they are told. These women's often metaphorical and ambiguous discourse about a daily reality of violence underlines the difficulty of sustaining a cohesive social reality by those living perennially under what they call 'the gaze of the wild' (Ibid.). One feels that there has to be a sort of discursive domestication of violence, both by victims and families of perpetrators, in order to 'mask terror'. Let us not forget that 'to mask' means 'to hide', 'to disguise', 'to justify', but it can also mean 'to embellish'. Many expressions travel between the discourse of spiritual religion and a discourse of interpersonal violence. Because language has to describe a new unknown reality, people have to coin new words or give old words new meanings, though some things are better left unsaid.

Ironically, women and the nation's history often meet during periods of war, where women are the most defenseless victims. But women also take part in building these same nations, both in colonial and postcolonial times. If history is another kind of narrative, what is then the role played by female characters in it?

\section{The Nation's Narrative}

According to the official discourse of independence and nation-building in Southeast Asia, women act as secondary characters in the nation's narrative, because the very definition of national history is destined to exclude or marginalise women. Colonial and post-colonial history concentrates on issues like inter-state diplomacy, political leadership and warfare, where men play the dominant roles, according to written sources that privilege male activities. In her introduction to Other Pasts: Women, Gender and History in Early Modern Southeast Asia, Barbara Watson Andaya emphasises that when the national story has already been laid out according to certain accepted formulae, women can only be included as a kind of supplement (Andaya, 2000). This has been especially evident in colonial and post-colonial history, where representations of nationalist movements and of the struggle against colonialism have been infused with masculine values. Histories already articulated in terms of themes such as the suppressed people, emergence of charismatic leaders, awakening of popular consciousness or a successful revolution have proved highly resistant to the incorporation of female characters and perspectives. 
But when narrating the nation's predicaments, patriarchal discursive productions often resort to stereotypes and metaphors associated with women, like honour, respectability, victimisation, maternity, protection and care, thus 'gendering' the mother nation, as if it were a fragile imaginary female entity. This is the main conclusion of Neloufer De Mel's essay 'Setting the stage, gendering the nation', included in Women and the Nation's Narrative: Gender and Nationalism in Twentieth Century Sri Lanka (De Mel, 2001). The book explores the development of nationalism in Sri Lanka during the past century, particularly within the dominant Sinhala Buddhist and militant Tamil movements. Tracing the ways women from diverse backgrounds have engaged with nationalism, De $\mathrm{Mel}$ argues that gender is crucial to an understanding of nationalism and vice versa, in several essays whose suggestive titles are, among others: 'Framing the Nation's Respectability', 'Agent or Victim? The Sri Lankan Woman Militant in the Interregnum' and 'Mother Politics and Women's Politics? Notes on the Contemporary Sri Lankan Women's Movement'.

Indeed, nationalism and patriarchy are never static institutions. They shift and adapt to circumstances and sometimes even adopt an apparent feminist stance, appropriating (meaning 'exploiting') the discourse of women's rights. But women also act on their own behalf and negotiate with patriarchy, capitalism and political opportunities, while exploring contradictions within nationalism itself, to their advantage. Universal values concerning conventional female roles are also present in some strategies used to induct women into politics, a field traditionally characterised by male dominance, as happened in Megawati Sukarnoputri's 1999 campaign:

During and after the June elections, not only Megawati, but also many other women in Indonesia began reclaiming a significant role in the political life of the country. Apart from adding their voice on national issues, they have also sought more attention for women's issues, including demands for more jobs in the bureaucracy, from village head to ministerial positions, and access to credit. No doubt these new political 'beginners' may become role models for less active women to enter public life. (Machali, 2001, p. 2)

In Indonesia, under Suharto's New Order regime, people were systematically depoliticised, a strategy that, towards women, took the form of 'state ibuism', from the Malay-Indonesian term $i b u$ (wife). In this 'housewification' process, women are socially defined as dependent housewives, a 
convenient strategy of social control and capitalist (re)production. This was a general setback to the women's cause in contrast to the rather egalitarian orientation of the revolutionary struggle against Dutch colonisers and the political campaigns of the mid-1950s. Although Megawati Sukarnoputri's campaign also used representations of female power, these were always protected and justified by the sacred inheritance of her father's name and mission (see also Barreira, 2001). The continuity of male power was the reason for Megawati's own struggle for power, because she was acting in the holy name of the father. She was not herself, she was 'the daughter of'. Once her father was avenged, she would simply return to the role of $i b u$, wife and mother, ruling her country as peacefully as any other housewife rules her home and supports her husband.

This self-interested legitimation of hierarchical power structures relies on a binary stereotyped opposition between genders, which justifies and perpetuates the division of society into a privileged group of leading men and a vast majority of powerless 'others', where women are always included. The artificial dichotomies thus created rationalise this type of situation, making it appear as natural and sensible. Derrida has shown how the construction of an identity is always based on exclusion and on a violent hierarchy within the resulting dichotomous pairs, as in the binominal pairs 'man/woman' or 'white/black' (or 'Western/Eastern'): 'What is peculiar to the second term is thus reduced to the function of an accident as opposed to the essentiality of the first. It is the same with the black-white relationship, in which white, of course, is equivalent to "human being". "Woman" and "black" are thus "marks" (i.e., marked terms) in contrast to the unmarked terms of "man" and "white" (Laclau, 1990, p. 33).

\section{Stereotypes, Dichotomies, Metaphors and Power}

Most texts we have seen refer to several types of stereotypes, dichotomies and ideologically oriented metaphors about gender related issues in general and the role of women in particular. Moreover, traditional forms of stereotyping gender hegemony have been replaced by other powerful, if somewhat more covert, forms, such as the ones pointed out by Robert Connell in Gender and Power: Society, the Person, and Sexual Politics: 
(a) the hierarchies and work-forces of institutionalised violence-military and paramilitary forces, police, prison systems; (b) the hierarchy and labour force of heavy industry (for example, steel and oil companies) and the hierarchy of high technology industry (computers, aerospace); (c) the planning and control machinery of the central state; and (d) working-class milieux that emphasize physical toughness and men's association with machinery. Connell (1991, p. 109)

In his The History of Sexuality, Foucault wrote 'power is everywhere; not because it embraces everything, but because it comes from everywhere' (Foucault, 1990, p. 93). Indeed, in the context of this article, even modern popular culture (music, cinema, television, Internet, novels and magazines) emerges as a new form that reinforces old structures of power that subordinate women. A popular novel, for instance, in order to be 'popular' and profitable, has to be an intricate composition, which expresses and mirrors existing everyday issues, while having the additional merit of subtly educating society towards alternatives to replace stereotypes. These concerns are delicately expressed without acknowledging a definite but unknown utopia for women and without disturbing the balance of an actually patriarchal society.

In modern popular culture, global concepts are localised according to frequently imposed roles and expectancies for local women. Although originally deriving from Western ideas, representations of romance, for instance, have taken a life of their own in media images and are rampant in popular culture throughout Asia (Soucy, 2001). The ideal of the happy family as the basic cell of society is prevalent and it is primarily women who are held responsible for its creation. In women's magazines, the connection between happiness, family and love is explicit. And, once again, we find here the inside/outside (home versus the world) dichotomy, where the male-dominated outside is accorded more prestige than the femalesupervised inside. Popular ideals of romantic love effectively reinforce gender hegemony, because of the non-confrontational way in which they are presented. In a nutshell, women no longer serve men because that is what they were supposed to do under the patriarchal system; they now do so because it is an expression of their true romantic love, which will ultimately reward them with a model happy family.

In Indonesia, everyday language itself shows that when a couple is the same age, the woman is referred to as a young sibling (adik), and the 
man as older brother (kakak). Thus, a relationship that positions men above women in a hierarchy of reference is seen as romantic. At a much more dramatic level, the concepts of domestic violence and marital rape may find acceptance difficult, as in Indonesia religious experts argue that husband and wife are 'two in one', and therefore rape cannot happen in marriage, because raping one's wife is similar to raping oneself. Moreover, this issue is regarded as a Western concept, spread by Western feminists and believed to be inappropriate for Indonesia, where feminism has commonly been viewed as opposition to men rather than an effort to empower women (Idrus, 2001). Ironically, economic domination by women does not guarantee the absence of violence: wives who are the breadwinners in the family also experience sexual violence from their dependent husbands. Further, women's awareness does not ensure that women will leave a violent marriage: duty, economic dependency, shame, guilt, the low social status of a divorcee, fear of losing custody of children and general acceptance of one's lot are the main factors promoting silence whenever violence happens in the private sphere.

The question of pregnancy and motherhood as an institution and/or experience recalls Julia Kristeva's dichotomies, 'nature' versus 'culture' and 'singularity' versus 'ethics'. Indeed, in her essay 'A New Type of Intellectual: The Dissident', Kristeva argues that motherhood can be seen as a bridge between singularity and ethics and that women in general stand on the threshold of socialisation, simultaneously ensuring social stability and permanently threatening that same stability (Kristeva, 2002). Motherhood, in fact, can be used to create a safe space for protest, protected by institutionalised discourses, as Malathi de Alwis advocates (Alwis, 2001 [1998]). In Sri Lanka, during the peak of state repression (between 1988 and 1990), the 'Mothers' Front' rose to protest against the 'disappearance' of nearly 60,000 young boys and girls, an issue that was conveniently silenced. The Mothers' Front used the institutional discourse of motherhood to project essentialist views on women that reinforced the notion of biology as destiny, legitimising the system of rigid gender roles. However, the unquestionable authenticity of their grief and their clear support of traditional family values within a patriarchal society, granted the movement an important space of protest, recalling the heroic example of the 'Madres de Plaza de Mayo', impossible for other organisations challenging state practices. 
Moving between fact and fiction, women novelists play an important role in transmitting stereotypes, dichotomies and associated social values through multiple perspectives, no matter whether their writing is popular or highbrow. Women novelists not only encode or affirm the values of their society but may also challenge, modify or give new meanings to those values through the formal strategies of literature. However, one must not forget that the concept of 'women's writing' itself can be a patronising stereotype that creates an underlying dichotomy, with 'men's writing', understood as 'the writing' — unmarked term (again Derrida) — in other words, as mainstream writing or mankind's writing, women '(not) writing like a man'. By and large, most women writers seem to continue to be more exposed than men to critical opinion by the media and academia and to the prejudices of a still largely conservative reading public.

When editing and translating The Lioness in Bloom: Modern Thai Fiction about Women, Susan Fulop Kepner proved herself aware of the essential dichotomy that imprisons Thai women between the fictional imperative of beauty, fragility and kindness (the flower) and the duty of fierce competition (the lioness), in the cumulative defence of home, family, career, status; in short, women are prisoners of the type of female perfection which is perennially required (Kepner, 1996). This critical collection of short stories and narratives focuses on the lives of Thai women of different ages and geographical and social origins, over seven decades of the 20th century. This collection includes texts that range from the formal literature of the 1930s to contemporary short stories written in a colloquial tone, from light comedy to the realism of tragedy. The Lioness in Bloom conveys a plural gender perspective, because it is 'about women', rather than a collection of texts written by women. However, these texts are organised into three sections entitled 'Mothers', 'Wives and Lovers' and 'Daughters'. Women are viewed through their family ties or their relationships with men; there seems to be a (self?) imposed impossibility of an autonomous identity. There is an oppression of the relational in the construction of identity, where the male element always serves as the referent. This may be due to the hegemonic standpoint of the authors, the personal or commercial choices of the publisher, or to an effective lack of options in choosing texts. But above all, it illustrates how the intersections and contingencies underlying issues of gender in Southeast Asia are also active on the literary scene. 
Thelma Kintanar, Ungku Tahir, Koh Ann and Toeti Heraty study these contingencies in Emergent Voices: Southeast Asian Women Novelists, concentrating on works from Malaysia, Brunei, Singapore, the Philippines and Indonesia (Kintanar et al., 1995). The situation of women novelists in these countries is not static but is developing in ways that are sufficiently encouraging to enable us to say that they are beginning to make an impact on their society. Education is one of the major preoccupations of their works, although the cultural contexts vary. Education is seen not only as a means of fulfilment for a woman but as a means of freeing her from the bondage and extreme subordination that is her fate in a strict traditional order. In Filipino novels by women, because of the educational history of the country, which gave women relatively early and equal access to higher education, the need for education for women is not a predominant theme, as it is in Malay and Indonesian novels. Indonesian popular novels by women writers present selfless heroines, dedicated to work, family and society, faithful to traditions and customs, meekly accepting everything that occurs in their lives. The underlying theme in such novels is social injustice towards women at different phases of their lives in the context of a patriarchal society: how women deal with sexuality, whether in or outside marriage; the problems faced by a single woman in society, especially if she is a widow or a divorcée; the choice of a career as an alternative for the modern woman and its implications and complications in Indonesian society. Conversely, in the Filipino novel, injustice towards women is seen as a part of, or subsumed under, social injustice as a whole.

It is evident that in different cultural contexts, Southeast Asian women novelists produce different kinds of work. As the search for local concepts actually generates new concepts, there has to be epistemological and phenomenological adaptation while studying gender related issues in Southeast Asia.

\section{In Search of Local Concepts: Localising Feminism}

When talking about gender studies, Southeast Asia must be understood in terms of colonialism, post-colonialism, capitalism, globalisation, and their diverse and intersecting discursive productions. Dutch feminists from the first half of the 20th century, for instance, were fully involved 
in the colonial project. Their criticism only addressed European women's exclusion from participatory colonial citizenship, not that of women of other population groups, a racial discrimination justified by a conservative interpretation of adat (tradition). Elsbeth Locher-Scholten's Women and the Colonial State deals with this ambiguous relationship between Indonesian and European women and the colonial state, in the former Dutch East Indies, between 1900 and 1942 (Locher-Scholten, 2000). This work is based on new data from a variety of sources, such as censuses, colonial archives, rural labour reports, household manuals, children's fiction and Indonesian press surveys. Women Creating Indonesia: The First Fifty Years, edited by Jean Gelman Taylor, also collects several insightful essays illustrating how, in a colonial context, democracy and feminism have always been severely limited (Taylor, 1997). Moreover, the men who have written the history of Westerners in Southeast Asia produced accounts that ignored the perspectives of wives, daughters, civil servants, travellers and female missionaries. Actually, history has thoroughly silenced the voices of women, both colonisers and colonised, both Eastern and Western.

Both Locher-Scholten and Taylor conclude that, of the intersecting categories of gender, race and class, class has remained the most restrictive and permanent. Indonesian female servants were certainly the ultimate Other-different in race, class, religion and gender from those who held power. On the other hand, Indonesian female servants were very close to the European families, as they took part in the most intimate areas of the household. Their presence offered many possibilities for ambivalence, fears and desires, as expressed in the textual representations of this social group. The truth is that the demands of modernity, the illusion of Westernisation, together with hopes for promotion in the colonial system, sometimes took the appearance of concern for the rights of women, as in the case of the rejection of polygamy. But the barriers of class prevailed. There was, for instance, little concern for the subsequent situation of secondary wives and concubines when polygamy was abolished, or for the cheap expendable female workforce of household servants, forgotten even by their Indonesian employers.

These, and other readings demonstrate how Western feminism has not always been aware, either voluntarily or involuntarily, of the cultural specificity of gender conditions in Southeast Asia. Adapting Clifford Geertz's thought, as expressed in Local Knowledge, feminist analysis 
and intervention should instead be defined by neither distancing 'others' (the 'other women') as counterpoles, nor drawing them close as facsimiles, but rather by locating itself among them:

In short, accounts of other peoples' subjectivities can be built up without recourse to pretensions to more-than-normal capacities for ego effacement and fellow feeling. Normal capacities in these respects are, of course, essential, as is their cultivation, if we expect people to tolerate our intrusions into their lives at all and accept us as persons worth talking to. I am certainly not arguing for insensivity here, and hope I have not demonstrated it. But whatever accurate sense one gets of what one's informants are, really does not come from the experience of that acceptance as such. It comes from the ability to understand their modes of expression, their symbol systems, which such acceptance allows to develop. Understanding the form and pressure of other's inner lives is more like grasping a proverb, catching an allusion, seeing a joke or reading a poem, than it is like achieving communion. (Geertz, 1993 [1983], p. 70)

Clearly, female empowerment means different things at different times in history, as a result of cultural, religious, economic, political, social and also individual circumstances. However, no matter how much feminist agendas might be made up to resonate with women's everyday experiences under all those circumstances, ideas alone are not enough to put effective pressure on the state and society. In other words, empowerment needs to be perceived both as something 'that comes from the women themselves and something they can own with pride' (Rowlands, 1998, p. 3), in individualised forms of everyday resistance; and as a strategy for action, implemented by governments and institutions alike and accepted - and put into practice - by society in general. Because, in reality, in male-dominated societies, though women may be permitted to engage in contained activism, women mobilising themselves around highly organised global feminist agendas are unlikely to receive such indulgence.

In brief, most women in Southeast Asia face numerous barriers to activism and find it hard to make their voices heard. Regional and class differences in domestic organisation and in women's access to education and income give some women more opportunities for mobilisation than others. Such examples often expose the fragmentation - by local domi- 
cile, class, ethnicity, religion and many other factors - that is highly likely to harass feminist organisations. But they also confirm the high levels of consciousness among women with no previous exposure to feminism as conventionally understood, and the tenacity and determination of women fighting for their rights in the face of obstacles. Resisting the Sacred and the Secular: Women's Activism and Politicised Religion in South Asia, edited by Patricia Jeffery and Amrita Basu, studies this particular type of resistance, focusing on women's agency and activism within the Southeast Asian context and their paradoxical relationship with religious politics in India, Pakistan, Sri Lanka and Bangladesh. In fact, contrary to the hopes of feminists, many women have responded to religious nationalist appeals; contrary to the hopes of religious nationalists, they have also asserted their gender, class, caste and regional identities; contrary to the hopes of nation states, they have often challenged state policies and practices.

Patricia Jeffery's own contribution, 'Agency, Activism, and Agendas', is particularly significant, especially when she clearly states that women's movements are invariably situated within specific national contexts of state and economy: 'The countries of South Asia have had different experiences of state and civil society, electoral politics and military rule, theocracy and secularism. Their economies and their integration into the world economy have taken different trajectories' (Jeffery, 2001 [1998], p. 238). Consequently, all these specificities must be integrated into individual feminist agendas.

Yet, if women experience oppression in locally specific ways, these experiences are by no means simply local in their origins and cannot be effectively combated at a restricted, fragmented level alone, which will only yield limited effects. Wherever they are, then, feminists cannot ignore the global dimensions of gender issues any more than their locally specific manifestations. Localisation and globalisation-with their associated discursive productions - are not another dichotomy: localisation cannot be projected as a counterpoint to the global but is itself a significant dimension of globalisation. Local knowledge is in dynamic tension with global knowledge. And the issue of gender is very much at the heart of all these dynamics, strongly related to historical, cultural, ethnic and class specificities, which require an interdisciplinary, transnational approach. 


\section{Conclusion: Converging Interests, Returns and Intercultural Transits}

Any contemporary research that relates issues of gender with capitalism, post-colonialism and post-modernism finds an extraordinary field of research all over Southeast Asia. A whole multitude of voices, diffuse genres, myriad points of view and consequences of multinational capital converge in the daily life of places as disparate as the clubs of Bangkok, the markets of Sumatra or the forests of Borneo, among many others throughout Southeast Asia, where new experiences and fields of knowledge are continually produced and intersect. Although James Clifford considered that among the normative practices of modern anthropology, ethnography has privileged relations of permanence, to the detriment of relations of movement; this perspective has changed as a result of the endless mobilities that travel the world today (Clifford, 1997). The intersecting routes of Southeast Asia have revealed much of the nature of modern Asian travel cultures and their conditions of emergence. The routes of traders, travellers and tourists mark the categories and the nature of interactions between Southeast Asia and the rest of the world, constructed and mediated in multiple ways. When analysed, these interactions emphasise the complexity of those diverse mobilities and their influence over local communities.

Following the course of this epistemological inflection, the intercultural transits that occur in the geographic area between Burma and the Philippines are analysed in Converging Interests: Traders, Travelers and Tourists in Southeast Asia; the authors have explored both remote communities - the so-called 'primitive' societies, internationally famous due to colonial, ethnographic and tourism-related interests - and hybrid places, that have evolved idiosyncratically into tourist centres, always focusing on movement as an essential condition for the construction of identities such as 'merchant', 'traveller', 'tourist' and 'tourist attraction' (Forshee, Fink and Cate, 1999).

It is undeniable that certain narratives and pioneer images of places like Vietnam, Thailand, Burma and Bali, produced by travellers, settlers, ethnographers and Western artists, still perpetuate in the present images and stereotypes about the exotic Orient and motivate much of the attraction that such places exert over tourists. There is a clear neo-colonialism 
in this search for new domains of pleasure and adventure, which includes an eroticised vision of the exotic Oriental woman. These verbal and iconic discourses have built a 'pleasure periphery' - to quote the designation given by Louis Turner and John Ash (1975) - promoted with great profit by tourism industries of the Western world. Indeed, one of the keys to understand the power nowadays exercised by Southeast Asian tourist attractions is nostalgia, the sentimental search for sensations and objects from the past, built over romantic colonial narratives. Colonial stereotypes emerge in many guidebooks, brochures and television commercials, as is evident in the familiar image of the graceful flight attendant of Singapore; in the luxury oriental-style hotel; in the appeal of trails across the jungle in search of remote and primitive tribes; or in the quest for a primordial and purifying Buddhism. Or, in a more sinister perspective, in the innocence of a Thai child prostitute; in the wild boy rescued from the jungle by human trafficking networks; or in the faithful servility of a Filipino servant (needless to say, all these statements are painfully ironic). In fact, promotional travel literature about Southeast Asia acts as an extension of those discourses that create a diffuse view of the Westerner over the 'East' (Said, 2004 [1978]), often ignoring actual social, cultural and historical distinctions, by emphasising a pseudo-tropical exoticism.

However, despite this dialectic between real and staged authenticity, most Southeast Asian governments have invested heavily in the lucrative tourism industry. Serious investment on infrastructure and advertising has brought huge economic gains, with tourism becoming a major source of income in many countries. Social relations and cultural trends have suffered deep changes, as the population of Southeast Asia, from the most varied backgrounds, seek to use the opportunities generated by tourism to relocate themselves within local structures. Ethnic, gender and class relations have been questioned or transformed, as groups and individuals try to translate the resources of tourism into increasing social and political power. Similarly, the growing demand for attractive native products (including here the human product), commonly described as 'traditional', 'ethnic' or 'primitive', results in their commodification and mass production for the international market. The international trade of local Southeast Asian crafts has transformed regions like Bali in Indonesia or the city of Chiang Mai in Northern Thailand into the marketplaces of a whole nation, 
attracting goods and people from the remotest regions. These new trading centres and sources of economic profit for local producers have promoted social relationships and dynamics otherwise unimaginable.

These 'converging interests' are evident in the expectations of tourists and in the relations of power that shape the stereotypical notions that international travellers have of native people. These notions and expectations transform the regions affected by tourism, to the extent that indigenous people adapt their daily practices to the new social and economic demands. However, local communities often respond to such pressures with their own strategies, innovations and subversions, and seldom remain passive within the process of incorporation into large-scale political and economic systems. Networks and echoes emanating from international tourism spread rapidly throughout the global market and its multiple forms of cultural interaction often bring with them their own forms of manipulation and subversion of power. These actions carried out in the 'peripheries' of the Western world - and which are, in turn, central to the lives and experiences of individuals - have been designated and described, more or less metaphorically, as 'borderzones' and 'borderlands', 'intersecting discursive fields', 'Bakhtinian carnivals', 'global ethnoscapes', 'trade diasporas' or 'a space on the side of the road', all of them reflecting the dialogic nature of culture and subjectivity (see Anzuldúa, 1987; Appadurai, 1991, pp. 191-210; Bakhtin, 1984; Bruner, 1996; Steiner, 1994; Stewart, 1996; Tsing, 1993). In the vast cultural diversity of Southeast Asia, past and present, global and local, converge in the analysis of concepts and issues of gender, closely related to the ongoing political, economic, social and cultural transformations. Southeast Asia is also an area of cultural intersection, as far as gender is concerned, of permanent cultural translation, that is, of reinterpretation, of repositioning of symbols and signs within existing hierarchies. In its critical readings, this article has attempted to look beyond the arbitrary meanings directly or indirectly assigned to issues of gender, favouring contextualised interpretations that, in their permanent uncertainty, are likely to produce new hypotheses, theories and explanations. This constant intercultural translation encourages the return to questions persistently excluded from hegemonic discourse (be it political, academic or derived from plain common sense), to adopt the concept of the 'return of the excluded', used by the American feminist Judith Butler (Butler, 1996; Butler et al., 2000). Butler seems to be more optimistic than Gayatri 
Spivak who in 'Can the Subaltern Speak?' asserted that historical and ideological factors have silenced the voices of those living in the national and global suburbs. To those excluded, whose epitome are non-Western women, in their silent subordination, Spivak does not grant Butler's hypothesis of 'return', since in her view, the very Western feminism has contributed to the construction of that silence, by denying a voice to the subaltern 'other' (Spivak, 1992).

For Butler, the universal-here understood as a synonym of hegemony, a Gramscian combination of power and consent (Gramsci, 1971) - can only be conceptualised in dialogue with its own peripheries, the 'borderzones', 'spaces on the side of the road' and other metaphors. Thus, what has been excluded from the concept of universality forces this same concept - from the outside, from the margins - to accept it and include it again, which can only happen when the concept itself has evolved enough to include its own excluded. This pressure eventually leads to the rearticulation of the current concept of universality and its power. The process through which universality readmits its own excluded, Butler calls 'translation'. Cultural translation — as the 'return of the excluded' - is a major force of contemporary democracy, challenging boundaries, fostering the evolution of society and opening new paths for emancipation, through subversive practices that alter everyday social relations. For both Homi Bhabha and Boaventura de Sousa Santos, the potential for change lies in the peripheries marked by hybridity, where newcomers (the excluded who return: women, migrants, people of the so-called third world, ethnic minorities, the poor, the 'Oriental') have the possibility of using subversion to undermine the strategies of power, regardless of the shape this power may assume (Bhabha, 1994; Santos, 2001, 2006, 2008).

One may conclude that the comparative approach necessary for any kind of intercultural analysis in Southeast Asia, as anywhere else in the world, has moved away from an anthropological notion of single culture, towards a notion of cultures in the plural, in a permanent dialogue, movement and translation, as Clifford Geertz (1993 [1983], p. 70) explains in Local Knowledge:

The hallmark of modern consciousness is its enormous multiplicity. For our time and forward, the image of a general orientation or perspective, growing out of humanistic or scientific studies, and shaping the direction of culture, 
is a chimera. (...) The conception of a 'new humanism', of forging some general 'the best that is being thought and said' ideology and working it into the curriculum, will then seem not merely implausible but utopian altogether. Possibly, indeed, a bit worrisome.

\section{References}

Alwis, Malathi de. (2001 [1998]). Motherhood as a space of protest: Women's political participation in contemporary Sri Lanka. In Patricia Jeffery \& Amrita Basu (Eds), Resisting the sacred and the secular: Women's activism and politicised religion in South Asia (pp. 185-201). New Delhi: Kali for Women.

Andaya, Barbara Watson (Ed.) (2000). Other pasts: Women, gender and history in early modern Southeast Asia. Honolulu: University of Hawai'i at Manôa, Center for Southeast Asian Studies.

Anzuldúa, Gloria. (1987). Borderlands/La frontera: The new mestiza. San Francisco: Spinsters/Aunt Lute Foundation.

Appadurai, Arjun. (1991). Global ethnoscapes: Notes and queries for a transnational anthropology. In Richard Fox (Ed.), Recapturing Anthropology (pp. 191-210). Santa Fe: School of American Research.

Argenti-Pillen, Alex. (2003). Masking terror: How women contain violence in southern Sri Lanka. Philadelphia: University of Pennsylvania Press.

Bakhtin, Mikhail. (1984). Rabelais and his world (translated by Helene Iswolsky). Bloomington: Indiana University Press.

Barreira, Irlys Alencar Firmo. (2001). Ritualisations du féminin lors d'une campagne électorale au Brésil. Anthropologies et Sociétés, 25(3), 31-49.

Bassnett, Susan, \& Lefevere, André. (1998). Constructing cultures: Essays on literary translation. Clevedon: Multilingual Matters.

Benería, Lourdes, \& Roldan, Martha. (1987). The crossroads of class and gender. Chicago: University of Chicago Press.

Bhabha, Homi. (1994). The location of culture. London and New York: Routledge.

Bruner, Edward M. (1996). Tourism in the Balinese Borderzone. In Smadar Lavie \& Ted Swedenburg. (Eds), Displacement, diaspora, and geographies of identity (pp. 157-179). Durham: Duke University Press.

Butler, Judith. (1996). Universality in culture. In Joshua Cohen (Ed.), For love of country: debating the limits of patriotisms (pp. 45-52). Boston: Beacon Press.

Butler, Judith, Laclau, Ernesto, \& Zizek, Slavoj. (2000). Contingency, hegemony, universality: Contemporary dialogues on the left. London and New York: Verso.

Chatterjee, Partha. (1993). The nation and its fragments: Colonial and postcolonial histories. Princeton: Princeton University Press. 
Clifford, James. (1997). Travel and translation in the late twentieth century. Cambridge, MA, and London: Harvard University Press.

Connell, Robert. (1991). Gender and power: Society, the person, and sexual politics. Cambridge: Polity Press.

De Mel, Neloufer. (2001). Women and the nation's narrative: Gender and nationalism in twentieth century Sri Lanka. Lanham, MD: Rowman and Littlefield.

Elson, Diane, \& Pearson, Ruth. (1981). Nimble fingers make cheap workers: An analysis of women's employment in third world export manufacturing. Feminist Review, 4(8), 87-107.

Forshee, Jill, Fink, Christina, \& Cate, Sandra (Eds). (1999). Converging interests: Traders, travelers and tourists in Southeast Asia. Berkeley: University of California Press.

Foucault, Michel. (1990). The history of sexuality (translated by Robert Hurley). New York: Vintage Books.

Gamburd, Michele Ruth. (2000). The kitchen spoon's handle: Transnationalism and Sri Lanka's migrant housemaids. Ithaca and London: Cornell University Press.

Geertz, Clifford. (1973). The interpretation of cultures. New York: Basic Books.

- (1993 [1983]). Local knowledge: Further essays in interpretive Anthropology. London: Fontana Press.

Gramsci, Antonio. (1971). Selections from the prison notebooks (translated by Quintin Hoare). London: Lawrence and Wishart.

Idrus, Nurul Ilmi. (2001). Marriage, sex and violence. In Susan Blackburn (Ed.), Love, sex and power: Women in Southeast Asia (pp. 43-56). Victoria (Australia): Monash Asia Institute.

Jayaweera, Swarna (Ed.) (2002). Women in post-independence Sri Lanka. New Delhi and London: SAGE.

Jeffery, Patricia (2001[1998]). Agency, activitism and agendas. In Patricia Jeffery, and Amrita Basu (Eds), Resisting the sacred and the secular: Women's activitism and politicised religion in South Asia (pp. 221-243). New Delhi: Kali for Women.

Jeffery, Patricia, \& Basu, Amrita (Eds) (2001 [1998]). Resisting the sacred and the secular: Women's activism and politicised religion in South Asia. New Delhi: Kali for Women.

Kepner, Susan Fulop (Ed.). (1996). The lioness in bloom: Modern Thai fiction about women. Berkeley and Los Angeles: University of California Press.

Kintanar, Thelma B., Tahir, Ungku Maimunah, Ann, Koh Tai, \& Heraty, Toeti (Eds) (1995). Emergent voices: Southeast Asian women novelists. Quezon City: University of the Philippines Press. 
Kiribamune, Sirima, \& Samarasinghe, Vidyamali (Eds) (1990). Women at the crossroads: A Sri Lankan perspective. New Delhi: Vikas Publishing House.

Kristeva, Julia (2002 [1986]). A new type of intellectual: The dissident (translated by Sean Hand). In Toril Moi (Ed.), The Kristeva reader (pp. 292-300). Oxford: Blackwell Publishing.

Laclau, Ernesto. (1990). New reflections on the revolution of our time. London: Verso.

Locher-Scholten, Elsbeth. (2000). Women and the colonial state: Essays on gender and modernity in the Netherlands Indies 1900-1942. Amsterdam: Amsterdam University Press.

Machali, Rochayah. (2001). Women and the concept of power in Indonesia. In Susan Blackburn (Ed.), Love, sex and power: Women in Southeast Asia (pp. 1-30). Victoria (Australia): Monash Asia Institute.

Mbembe, Achille. (1992). The banality of power and the aesthetics of vulgarity in the postcolony. Public Culture, 4(2), 1-30.

Mohanty, Chandra. (1988). Under western eyes: Feminist scholarship and colonial discourses. Feminist Review, 30, 61-88.

Nayar, Usha. (1988). Women teachers in South Asia: Continuity, discontinuity and change. Delhi: Chanakya Publications.

Ong, Aihwa, \& Peletz, Michael G. (Eds) (1995). Bewitching women, pious men: Gender and body politics in Southeast Asia. Berkeley and Los Angeles: University of California Press.

Ong, Aihwa. (1988). Colonialism and modernity: Feminist re-presentations of women in non-western societies. Inscriptions, 3(4), 79-93.

Perera, Sasanka. (1999). Stories of survivors: Socio-political contexts of female headed households in post-terror southern Sri Lanka. New Delhi: Vikas Publishing House.

Rodgers, Susan (Ed.) (1995). Telling lives, telling history: Autobiography and historical imagination in modern Indonesia. Berkeley and Los Angeles: University of California Press.

Rowlands, Jo. (1998). A word of the times, but what does it mean? Empowerment in the discourse and practice of development. In Haleh Afshar (Ed.), Women and empowerment: Illustrations from the third world. (pp. 11-34). London: MacMillan.

Said, Edward W. (2004 [1978]). Orientalismo: Representações ocidentais do oriente (translated by Pedro Serras). Lisbon: Livros Cotovia.

Santos, Boaventura de Sousa. (2001). Entre prospero e caliban: Colonialismo, pós-colonialismo e inter-indentidade. In Irene Ramalho, \& António Sousa Ribeiro (Eds), Entre ser e estar: Raizes, percursos e discursos da identidade (pp. 23-85). Porto: Afrontamento. 
Santos, Boaventura de Sousa. (2006). A gramática do tempo. Para uma nova cultura política. Porto: Afrontamento.

. (2008). A filosofia à venda, a douta ignorância e a aposta de Pascal. Revista Crítica de Ciências Sociais, 80, 11-43.

Simon, Sherry. (1996). Gender in translation: Cultural identity and the politics of transmission. London and New York: Routledge.

Soucy, Alexander. (2001). Romantic love and gender hegemony in Vietnam. In Susan Blackburn (Ed.), Love, sex and power: Women in Southeast Asia (pp. 31-42). Victoria (Australia): Monash Asia Institute.

Spivak, Gayatri Chakravorty. (1992). Can the subaltern speak? In P. Williams, \& L. Chrisman (Eds), Colonial discourse and post-colonial theory (pp. 66-111). New York: Columbia University Press.

Steiner, Christopher. (1994). African art in transit. Cambridge: Cambridge University Press.

Stewart, Kathleen. (1996). A space on the side of the road: Cultural poetics in an "other" America. Princeton: Princeton University Press.

Taylor, Jean Gelman (Ed.) (1997). Women creating Indonesia: The first fifty years. Clayton (Australia): Monash Asia Institute.

Tolentino, Rolando. (1999). Bodies, letters, catalogs: Filipinas in transnational space. In Shirley Geok-Lin Lim, Larry Smith, \& Wimal Dissanayake (Eds), Transnational Asia Pacific: Gender, culture and the public sphere (pp. 43-68). Chicago: University of Illinois Press.

Tsing, Anna Lowenhaupt. (1993). In the realm of the diamond queen: Marginality in an out-of-the-way place. Princeton: Princeton University Press.

Turner, Louis, \& Ash, John. (1975). The golden hordes: International tourism and the pleasure periphery. London: Constable.

Wolf, Diane Lauren. (1992). Factory daughters: Gender, household dynamics and rural industrialization in Java. Berkeley and Los Angeles: University of California Press. 